\title{
The Dynamic of Repression: The Global Impact of the Stalinist Model, 1944-1953
}

\section{By Szalontai Balazs (Hungary)}

As long as Stalin was alive, no Communist regime except Tito's questioned openly the infallibility of the Soviet dictator, and adulation of the Vozhd' never was in short supply. As a consequence, a lot of historians and Sovietologists concluded that the smaller countries - with the possible exception of China had merely copied Soviet domestic policies, and imitation in toto had been explicitly prescribed by the ruler in the Kremlin. Soviet influence was indeed extensive but by no means absolute. Deviations from Soviet policies, though unpublicized that time, could be quite significant, and a comparative analysis may contribute to the reinterpretation of Soviet Stalinism. Asymmetrical and normative comparisons, however, would hardly facilitate such efforts. While one should not regard the policies of the various Communist parties and regimes merely as the reflection of previous or contemporary Soviet domestic and foreign policies, undue emphasis on the 'method of difference' may contrast the comprehensive analysis of a 'satellite' regime with a frozen and simplified image of Soviet Stalinism. One also should be aware of that the similarity or difference of institutions and policies did not necessarily indicate political sympathy or aversion: in a number of cases they simply reflected the specific socioeconomic and political realities of a country.

For various reasons, this essay concentrates on a single aspect of Stalinist policies, namely, political repression. The whole 'Stalin phenomenon,' due to its great complexity, could not have been covered adequately on the pages of a short study. (It was the same factor that prevented the author from making a comparison between Soviet and Chinese policies. China's enormous size, its special status within the 'Soviet bloc,' and the peculiar traditions of the Chinese Communist guerrilla movement would have necessitated such an extensive analysis that proved incompatible with the framework of this essay.) This emphasis on repression, however, does not mean the ,criminalization” of Soviet and Communist history. Stalinist policies proved inseparable from terror, but the dynamic of repression was also influenced by factors beyond the horizon of

* This is a revised version of the orginial, which was first published in Russian History/Histoire Russe, Issue 2-4 (2003), pp. 415-442 
security chiefs and labor camp commandants. It is tempting to explain the Great Terror by simply emphasizing the destructive potential of Communist ideology, yet that ideology did not always lead to a destruction of such a magnitude. While every Stalinist regime was repressive enough, the slaughter of tens and hundreds of thousands did not take place in every country ruled by a Stalinist dictatorship. The mere existence of certain less destructive alternatives refutes those interpretations which regard even the worst manifestations of political (not necessarily Communist) repression as having been somehow predetermined by ideological factors. Quite paradoxically, these explanations actually understate the personal responsibility of the various dictators.

\section{Prelude in Mongolia}

By the time the Red Army entered Eastern Europe, the Soviet leaders had gained substantial experience in establishing and controlling a satellite regime. Moscow's ,oldest political satellite” (George G. S. Murphy) was the Mongolian People's Republic, proclaimed in 1924. According to Zoltan Barany, ,it appears that Soviet leaders learned many tricks of the 'takeover trade" " in Mongolia. ${ }^{1}$ In any case, this similarity is a good argument for a comparative study, but the differences between Mongolian and East European policies may reveal even more about the dynamic of Stalinist repression. In addition, the comparative analysis of the Soviet and Mongolian purges may throw some light on the origins of Stalin's Great Terror. Since the policies pursued by the Mongolian leaders were often dictated by Moscow, it is all the more interesting that in several cases the timing and characteristics of these measures precluded the possibility of simple and indiscriminate imitation. In other words, the Soviet leadership (including Stalin) did not consider the Soviet political and economic model the sole correct one but devised different methods for Mongolia. It is necessary to point out, though, that these differences remained within the framework of a one-party dictatorship.

The Mongolian Communist party (known as Mongolian People's Party, then as Mongolian People's Revolutionary Party) was officially founded in 1920, and one year later the military assistance it received from the Red Army enabled it to seize power. The MPP/MPRP proved a far cry from the Bolshevik Party, however. Contemporary Mongolian society lacked an industrial working class, and since the party's initial program was reformist, rather than revolutionary, a

\footnotetext{
${ }^{1}$ Zoltan Barany, ,,Soviet Takeovers: The Role of Advisers in Mongolia in the 1920s and in Eastern Europe after World War II," in East European Quarterly Vol. XXVIII (January 1995), No. 4, p. 414.
} 
number of non-Communist nationalists, lamas and princes joined it in order to liberate the Mongols from Chinese rule. Due to its unusual social composition, feeble organization, and heterogeneous leadership, in the pre-1929 period the party did not play the same role in domestic politics as its Soviet counterpart. First of all, it could not control effectively the actions of its ultra-radical Youth League (Revsomols) but often felt threatened by the latter. The Soviets, on their part, made use of the frequent intra-party squabbles, and of the Revsomols's radicalism, to put pressure on certain 'rightist' party leaders, and intervened directly in Mongolian party affairs. ${ }^{2}$ As a consequence, MPP/MPRP leaders fell victim to purges much earlier than CPSU leaders would do. In 1922 Premier Bodoo was forced to resign, then arrested by the security service and shot. In 1924 a Revsomols death squad headed by Choibalsan executed Danzan, a former MPP chairman. Neither execution was preceded by any trial. ${ }^{3}$ The harshness of these repressive measures stood in marked contrast with the regime's quite moderate and flexible economic and cultural policies. For instance, the total number of lamas actually increased between 1924 and 1927, and the wealth of the Buddhist church remained largely intact. ${ }^{4}$ This dichotomy between the political and the economic spheres would be also characteristic of the 1930s and 1940s. The Mongolian dictatorship was a Communist regime, and a very repressive one, at that, but it did not become 'totalitarian' as quickly as its Soviet model.

In 1929 the leftist members of the MPRP leadership, following Soviet directives, launched a campaign against the country's traditional elites and attempted to force the nomadic herdsmen into cooperatives. That time Moscow certainly wanted to apply the Soviet model on Mongolia, but the attempt ended in a complete economic and political disaster. Livestock losses amounted to a third of the herds, and a very substantial part of the population rose in armed rebellion. While the MPRP leaders doggedly clung to their ultra-leftist line, Stalin concluded that the situation demanded the implementation of a 'New Turn Policy.' In 1932 the Mongolian government, having been rebuked by the Comintern, dissolved all cooperatives and most state farms, and returned the animals to private ownership. Forcibly secularized lamas could return to their monasteries, and certain categories of lamas regained their electoral rights. ${ }^{5}$

${ }^{2}$ Robert Rupen, How Mongolia is Really Ruled. A Political History of the Mongolian People's Republic 1900-1978 (Stanford: Hoover Institution Press, 1979), pp. 42-43.

${ }^{3}$ Shagdariin Sandag and Harry H. Kendall, Poisoned Arrows. The Stalin-Choibalsan Mongolian Massacres, 1921-1941 (Boulder: Westview Press, 2000), pp. 30-33, 52-55.

${ }^{4}$ C.R. Bawden, The Modern History of Mongolia (London: Weidenfeld and Nicolson, 1968), 258-261.

${ }^{5}$ Ibid., pp. 312-324., 352; Tsedendambyn Batbayar, „Stalin's Strategy in Mongolia, 1932-1936,” in Mongolian Studies Vol. 22 (1999), pp. 2-8. 
Collectivization would not be renewed until the mid-1950s, and other aspects of socioeconomic transformation along Communist lines (with the exception of the persecution of Buddhism) also received little emphasis in the 1932-1953 period. For instance, „the extension of general education to the Mongols did not take place until the late 1940's and the 1950's.” In 1934 the Soviets ,,handed control over joint Soviet-Mongol companies to the Mongols." The 'New Turn Policy,' a brainchild of Moscow, bore a resemblance to the 'New Courses' initiated in Eastern Europe in 1953-1954. This similarity questions the widely held assumption that attributes the post-1953 'New Courses' solely to Stalin's death. Since Stalin and Khrushchev resorted to quite similar methods in order to solve the political and socioeconomic problems of their respective satellites, leader-centric interpretations may overlook certain important aspects of the history of the Soviet regime. The continuity between the Stalin and the postStalin era did not manifest itself exclusively in the persistence of repressive measures. A tradition of self-correction also seems to have existed throughout the seven decades that followed the October Revolution, though 1953 was undoubtedly a milestone of crucial importance.

In the first half of the 1930s the Mongolian political system, and its repressive actions, still differed from the Soviet regime in several respects. First of all, Mongolian party purges and upheavals affected a significantly higher proportion of the membership than Soviet proverki did. In 1928-1929 the MPRP lost a third of its members; in 1932, three-fifths; and in 1934, four-fifths. Party membership dropped from 42,000 in 1932 to 8,000 in 1934. ${ }^{7}$ As a consequence, in 1933 a CC plenum reversed the previous relationship between the MPRP and the government, and strictly subordinated the former to the latter - an unlikely development in a Communist country. ${ }^{8}$ (The party would later regain its influence, however.) On the other hand, 1933-1934 proved an important watershed. In three big 'spy trials', more than 50 high-ranking party and state officials, military officers, and lamas were sentenced to death and some 260 to imprisonment on fabricated charges; a further 126 were taken to the USSR. The interrogators used torture in order to extract false confessions, and when CC Secretary Lhumbe, one of the chief defendants, refused to plead guilty, the security service took him to the Soviet Union for further torture. These refined methods of interrogation ,were used for the first time in Mongolia in dealing

\footnotetext{
${ }^{6}$ George G.S. Murphy, Soviet Mongolia. A Study of the Oldest Political Satellite (Berkeley-Los Angeles: University of California Press, 1966), p. 132-133., 144.

${ }^{7}$ Rupen, How Mongolia is Really Ruled, pp. 58-59.

${ }^{8}$ Bawden, The Modern History of Mongolia, pp. 330-360.
} 
with the Lhumbe Affair." The trials of the so-called Hentii and Eastern Groups took place in December 1933, while the Central Group (including Lhumbe) was prosecuted in July $1934 .^{9}$ That is, the methods characteristic of the Soviet Great Terror (the purge and execution of top party cadres, the staged trials, the systematic use of torture in order to extract false confessions, and the charges of espionage) had appeared in Mongolia more than a year before analogous events happened in the Soviet Union.

The lead the Mongolian purges took over their Soviet counterparts flatly contradicts the common image of a satellite copying the policies of its model. Does this fact also enable us to reinterpret the Soviet Great Terror itself? It may not, since, as indicated earlier, the Kremlin often pursued different policies at home and in the MPR. The execution of a CC Secretary on fabricated charges, unheard-of in the USSR before 1935-1936, was no novelty in Mongolia, a country that had lost such important leaders as Bodoo and Danzan as early as 1922-1924. On the other hand, certain aspects of the Lhumbe Affair deserve attention. While the purges of 1922-1924 had not been accompanied by Sovietstyle staged trials, the Lhumbe Affair, as well as the terror that would follow it in 1937-1939, was. The purge of 1933-1934 had been carefully planned by OGPU advisers Chibisov and Grigoriev, and it was OGPU officers Ratuzov, Iliev, Badmayan, and Sorokin who interrogated Lhumbe in the Soviet Union. Since the Soviet leaders, if they wanted to remove a Mongolian politician, could easily achieve this aim by exiling him to the USSR (as it happened to two ultra-leftist leaders, Badrakh and Shijee, in 1932), ${ }^{10}$ it is quite unlikely that they would have devised such sophisticated methods solely for Mongolian use if they had not intended to use them at home as well. A possible explanation is that as early as 1933 Stalin concluded that it had become necessary to execute at least some of his intra-party opponents. While in the Soviet Union such cruel methods, if used prematurely, could have been counterproductive, there was no comparable risk in the MPR, a country dominated by Moscow. The trials staged by the Mongolian regime resulted, from the very beginning, in the execution of some defendants. By contrast, in 1935 Zinoviev and Kamenev received only prison sentences, and it was their second trial that led to their execution. The gradualism that characterized the Soviet purges in 1934-1936 may have been rooted in Stalin's attempt to conceal his ultimate aims (and thus

${ }^{9}$ Bat-Erdene Batbayar, Twentieth Century Mongolia (Cambridge: The White Horse Press, 1999), pp. 329331; Sandag and Kendall, Poisoned Arrows, pp. 72-73.

${ }^{10}$ Batbayar, Twentieth Century Mongolia, pp. 320-321, 350-351. 
prevent the emergence of a determined opposition). ${ }^{11}$ Had Stalin's various victims known that they would be eventually executed, they may have created a united bloc capable of stopping the dictator's Juggernauth.

In 1935-1937 the Mongolian regime publicly tried several higher-ranking lamas, and when Stalin launched his Great Terror, the Mongolian dictator Choibalsan quickly followed suit. The Mongolian Great Purges began in September 1937 and lasted until the spring of 1939. It was the arrival of two new Soviet advisers, Glazkov and Militsin, that heralded the end of mass terror. Similarly to Yezhov, a number of Mongolian security chiefs directly responsible for the previous repressive measures (e.g. Nasantogtoh, Bayasgalan, and Dashtseveg) were eliminated in 1939, though the execution of several prominent party leaders, such as Laagan, Amar, Dogsom, Badrakh, and Shijee, took place as late as 1940-1941. These similarities were close enough to be explained by conscious, though hardly voluntary, imitation. In addition, the scope of the Mongolian Great Terror reached, or even surpassed, that of the Soviet Great Purges. At the end of 1939, Choibalsan noted in his diary that 56,938 persons (including 17,335 lamas) had been arrested between 1937 and November 1939, and 20,396 of them were executed. 36 of the $51 \mathrm{CC}$ members elected by the Fourth MPRP Congress, and all Presidium members except Choibalsan perished in the purges. ${ }^{12}$ By contrast, neither of the Soviet-dominated East European dictatorships (with the possible exception of the Hoxha regime) was responsible for a comparable intra-party bloodbath. Significantly, in January 1962 the Hungarian Ambassador to Ulan Bator reported that the number of victims had been ,disproportionately higher" in the MPR than in the other 'people's democracies. ${ }^{13}$ This difference is worth analyzing, and we will come back to that later.

\footnotetext{
${ }^{11}$ On the zigzags in Stalin's pre-1937 policies, see, among others, J. Arch Getty and Oleg V. Naumov, The Road to Terror. Stalin and the Self-Destruction of the Bolsheviks, 1932-1939 (New Haven-London: Yale University Press, 1999), pp. 578-582. Getty and Naumov rightly point out that Stalin did not face a coherent 'moderate bloc,' and he repeatedly proved more flexible than his lieutenants did. On the other hand, Stalin's ,angelic patience" may have been a conscious strategy to dissuade the (real and potential) opposition from taking a firm stand. The dictator seems to have pursued a ,stick and carrot" policy in order to make his potential victims believe that they were not in serious danger unless they somehow provoked Stalin.

${ }^{12}$ Batbayar, Twentieth Century Mongolia, pp. 359-372. See also, among others, Christopher Kaplonski, „Blame, Guilt, and Avoidance. The Struggle to Control the Past in Post-Socialist Mongolia," in History and Memory Vol. 11 (1999), No. 2, pp. 96-98.

${ }^{13}$ Hungarian Embassy to the MPR, Report, 23 January 1962, XIX-J-1-j [Top Secret Documents] Kнna 1945-1964 [henceforth CTS], 7. doboz, 5/bc, 0010/RT/1962. All the Hungarian archival documents referred to in this essay are available in the Hungarian National Archives (MOL).
} 


\section{The Wave of Post-Occupation Violence}

Apart from Mongolia, the Soviet Union had not had any satellite before World War II. In the 1944-1949 period, however, a number of Communist regimes were established in Eastern Europe and Asia. The circumstances of their conception and birth varied from country to country. In a free election held in 1946, the Czechoslovak party - uniquely in Eastern Europe - received more votes than any of its rivals, and its leader, Gottwald, became Prime Minister. In East Germany, Poland, Hungary, Romania, and North Korea the local Communist parties had to reckon with, and could rely on, the administration set up by the Soviet occupiers, while the Yugoslav, Albanian, and Chinese parties came to power due to their military triumph over various foreign and domestic opponents. (Soviet troops were withdrawn from Bulgaria and North Korea in 1947 and 1949 respectively.) The Bulgarian partisans would have hardly taken Sofia without the Soviet invasion of 1944, but the armed force they possessed was certainly a substantial one if compared to the ineffectiveness of the German, Hungarian, Czech, and Romanian Communist resistance movements. The Slovak and Korean guerrilla movements, though significant in certain periods of the war, had been largely stamped out before the entry of the Red Army. The Polish Communists also had a considerable fighting force of their own, but it did not operate as independently from Soviet troops as it was the case in Yugoslavia, Albania, and China. In 1945 the Vietnamese Communists, having created an anti-Japanese guerrilla force, succeeded in seizing power, but the return of the French prevented them from consolidating their regime in the whole country. While Hungary and Czechoslovakia had 'genuine multi-party coalitions' before 1947-1948, the other regimes (above all, Yugoslavia, Albania, and North Korea) began to manipulate elections and restricting the freedom of democratic opposition as early as 1945-1946.

In certain countries the establishment of the Communist regimes was accompanied with the execution of thousands of real and alleged political opponents. Since these executions usually claimed far more lives than the ones carried out in the 1948-1953 period, they deserve particular attention. Of the countries affected, it was probably Yugoslavia that experienced the worst violence. In May and June 1945 Tito's partisans executed more than 18,000 „Ustashas, White Guards, and Ljotic followers" (that is, members of Croatian, Slovene, and Serbian collaborationist organizations) near Kocevje. ${ }^{14}$ When

\footnotetext{
${ }^{14}$ Noel Malcolm, Bosnia. A Short History (London: Macmillan London Limited, 1994), p. 193; Jasper Ridley, Tito (London: Constable and Company Limited, 1994), pp. 254-257.
} 
partisan troops entered villages in Bosnia (and elsewhere), it often happened that ,all potential opponents, mainly people of higher social standing and intellectuals known to be believers, were simply put to death without any judicial proceedings or investigation." ${ }^{15}$ The mass executions carried out by the partisan forces in Vojvodina late in 1944 resulted in the death of thousands, possibly tens of thousands, of ethnic Hungarian civilians. ${ }^{16}$ The German minority similarly suffered high losses: some 60,000 individuals died in the internment camps run by the Yugoslav Communist authorities or en route, while another 15-20,000 were killed by partisan or Soviet troops. ${ }^{17}$

In 1944-1945 the newly established Albanian Communist regime launched a campaign against collaborators, northern (Gheg) nationalists, tribal leaders, upper-class families, Catholic priests, and intellectuals. Special tribunals, staffed entirely by judges with no legal training, sentenced thousands to death, forced labor, or imprisonment. Similarly to Chinese Communist practices, it was left to spectators, the latter having been instigated by the police, to determine punishment. ${ }^{18}$ In the same years Bulgarian Communist partisans executed or arbitrarily murdered thousands, possibly tens of thousands, of people. While some victims had indeed been closely associated with the royal dictatorship or the extreme right, many others merely belonged to the non-Communist intelligentsia, the Orthodox clergy, or the middle classes. Following these massacres, People's Courts sentenced 12,000 individuals to death for war crimes, of whom over 2,700 were actually executed. ${ }^{19}$ By 1948, after five years of armed struggle, the Polish Communist forces, backed by Soviet security and military units, had largely eliminated the Homeland Army (AK) and the other anti-Communist guerrilla movements. According to the Polish historian Maria Turlejska, the military tribunals set up by the Communist regime sentenced at least 2,500 persons to death, most of whom were executed. ${ }^{20}$ Following the 1945 collapse of French and Japanese rule in Vietnam, the Communist-led Viet

\footnotetext{
${ }^{15}$ Malcolm, Bosnia, p. 195.

${ }^{16}$ Tibor Cseres, Titoist Atrocities in Vojvodina 1944-1945. Serbian Vendetta in

Bacska (Buffalo-Toronto: Hunyadi Publishing, 1993), pp. 138-141.

${ }^{17}$ Rьdiger Overmans, ,,Personelle Verluste der deutschen Bevцlkerung durch Flucht und Vertreibung,” in Dzieje Najnowsze Vol. 26 (1994), Issue 2, p. 60.

${ }^{18}$ Isa Blumi, ,The Politics of Culture and Power: The Roots of Hoxha's Postwar State," in East European Quarterly Vol. 31 (September 1997), Issue 3, pp. 385-388; James O’Donnell, A Coming of Age. Albania under Enver Hoxha

(New York: Columbia University Press, 1999), p. 12.

${ }^{19}$ Nissan Oren, Revolution Administered. Agrarianism and Communism in Bulgaria (Baltimore-London: The Johns Hopkins University Press, 1973), pp. 79-80; Tzvetan Todorov, Voices from the Gulag. Life and Death in Communist Bulgaria (University Park: The Pennsylvania State University Press, 1999), pp. 38-42.

${ }^{20}$ Szokolay Katalin, Lengyelorszag tortenete (Budapest: Balassi Kiado, 1996), p. 206.
} 
Minh arrested tens of thousands of real or supposed collaborators, including members of the Dai Viet Party and the Vietnam Nationalist Party. Of these persons, ,several thousand alleged enemies of the Revolution failed to survive abductions of this kind in late August and September."21

Nevertheless, this type of mass violence was not characteristic of every Communist regime established in the wake of World War II. By and large, the East German, Czechoslovak, Hungarian, and Romanian Communist parties refrained from that particular method, though in other respects their policies proved repressive enough. Nor did the North Korean regime resort to mass executions in the 1945-1949 period; the outbreak of the Korean War, however, led to a sharp increase in the number of politically motivated executions and murders. ${ }^{22}$ To be sure, a few atrocities of this kind, while restricted in number, did take place in every country. In the spring of 1945 the self-appointed 'Communist' authorities of the Hungarian district of Gyomro (mostly men who had supported the short-lived Soviet Republic in 1919 but lost their contacts with the Communist party afterwards) tortured and murdered at least 18 alleged 'reactionaries,' including an anti-Fascist aristocrat who had recently got a safeconduct from Rakosi, the supreme leader of the Hungarian Communist Party. ${ }^{23}$ The leaders of these East European parties often found it difficult to hold the radicalism of lower-level cadres and rank-and-file party members in check. Many German Communists, who had spent the war years in the underground, or in Nazi concentration camps and prisons, thought that there was no need to cooperate with other anti-Fascist parties. „Some local communists began the collectivization of agriculture; others ... set up Soviets of Workers' and Peasants' Deputies." ${ }^{24}$ Still, the overall picture of Communist policies in these five countries did not include the mass execution of political opponents belonging to the majority ethnic group, though the German and Hungarian minorities in Czechoslovakia and Romania did suffer such atrocities at the hands of various (Communist and non-Communist) armed groups. (For instance, in the town of Presov 265 Germans, including 120 women and 4 children, were executed on the order of a Czechoslovak lieutenant in June 1945. ${ }^{25}$ ) Characteristically, the

\footnotetext{
${ }^{21}$ David G. Marr, Vietnam 1945. The Quest for Power (Berkeley-Los Angeles-London: University of California Press, 1995), pp. 234-237, 518-519.

${ }^{22}$ Hungarian Embassy to the DPRK, Report, 12 December 1955, XIX-J-1-j [Top Secret Documents] Korea 1945-1964 [henceforth KTS], 6. doboz, 5/cb, 00603/1956.

${ }^{23}$ Palasik Maria, ,A gyomroi gyilkossagok es kovetkezmenyeik, 1945-46,” in

Valosбg Vol. 38 (April 1995), Issue 4, pp. 58-61.

${ }^{24}$ Norman M. Naimark, The Russians in Germany. A History of the Soviet Zone of Occupation, $1945-$ 1949 (Cambridge [Mass.]-London: The Belknap Press of Harvard University Press, 1997), pp. 254-256.

${ }^{25}$ A.F. Noskova, ,Migration of the Germans after the Second World War: Political and Psychological Aspects,” in Journal of Communist Studies and Transition Politics Vol. 16 (March/June 2000), No. 1-2, p. 108.
} 
Polish and Bulgarian regimes established labor camps as early as 1944-1945, whereas Czechoslovakia and Romania followed suit only in 1948-1949.

Whence this difference? The political traditions of the countries in question seem to have played a limited role in these events. The Antonescu, Sztojay, and Szalasi regimes committed far more crimes against humanity than the Bulgarian governments, and the Romanian intelligentsia was much more influenced by the ideas of the extreme right than its Bulgarian counterpart. While both Budapest and Bucharest participated in Hitler's war against the USSR, Sofia did not. Nevertheless, the Bulgarian purges of 1944-1945 proved far more violent than the ones carried out by the Hungarian and Romanian Communists. In Hungary and Bulgaria the number of persons executed for war crimes and crimes against humanity stood at 146 and 2,700 respectively. According to official data, in East Germany the Soviet authorities sentenced 12,807 members of various Nazi organizations, of whom 118 received the death sentence. ${ }^{26}$ Most probably, the dissimilarities described above resulted primarily from the different strength of the various Communist resistance movements. As indicated before, only the Yugoslav, Albanian, Bulgarian, Polish, and Vietnamese Communist parties possessed a considerable armed force at the end of the war, and it was precisely these parties which carried out thousands of executions in 1944-1948. A thirst for revenge often seems to have played a role in the atrocities in question. For instance, of the 12,000 members the Yugoslav CP had had in 1941, threefourths perished in the war. ${ }^{27}$ In addition, the Yugoslav, Albanian, Polish, and Vietnamese anti-Communist opposition (e.g. the Chetniks, the Balli Kombetar, the AK, the Cao Dai, and the Hoa Hao) also could rely on armed groups - a factor that certainly shaped the characteristics of the conflict.

These facts seem to indicate that the mass executions described above should be put into the context of what one may term 'post-occupation violence.' Liberation from Fascist rule unleashed political passions in many countries, and the perpetrators of post-occupation violence - usually members of resistance organizations - were not necessarily Communists. According to data compiled by the French government, more than 4,000 collaborators were executed by maquisards in France during and after the Liberation. ${ }^{28}$ In Italy some 12-15,000 people died between April and June 1945 as the partisans revenged themselves on ex-Fascists. ${ }^{29}$ In Greece the Communist-led ELAS/EAM also executed a

\footnotetext{
${ }^{26}$ Hermann Weber, Die DDR $1945-1990$ (Munich: R. Oldenbourg Verlag, 1993), p. 10.

${ }^{27}$ Ridley, Tito, pp. 254-257.

${ }^{28}$ Peter Novick, The Resistance Versus Vichy. The Purge of Collaborators in Liberated France (London: Chatto and Windus Ltd., 1968), pp.204-206.

${ }^{29}$ David Travis, „Communism and resistance in Italy, 1943-8,” in Resistance and Revolution in Mediterranean. Europe 1939-1948. Edited by Tony Judt (London-New York: Routledge, 1989), p. 99.
} 
number of armed ex-collaborators without trial in 1944. This wave of violence was soon followed by a ,white terror." ${ }^{30}$ Disregarding the Varkiza Agreement of February 1945, the National Guard and various paramilitary groups killed over 1,200 leftists that year. „Over eighty thousand people were prosecuted during 1945 , the overwhelming majority belonging to the Left." ${ }^{31}$ The expulsion of the Sudeten Germans from Czechoslovakia resulted in some 30,000 deaths. ${ }^{32}$ Significantly, it was not only the local Communist parties which demanded the deportation of the Germans from Czechoslovakia and Poland. The exile governments in London, as well as several non-Communist parties active at home, similarly endorsed the demands for expulsion. ${ }^{33}$ In Hungary certain parties, e.g. the Social Democrats, condemned the principle of indiscriminate deportation, but several anti-Communist democrats, such as the General Secretary of the National Peasant Party, pressed for the expulsion of the whole German minority. ${ }^{34}$

That is, the arbitrary execution of political opponents was not solely a Communist method. On the other hand, the targets of the Yugoslav, Albanian, Bulgarian, and Polish CPs included not only Fascists and collaborators (as it was the case in France and Italy) but also anti-Communist democrats and individuals who merely belonged to social strata which the Communists regarded as 'exploitative.' These acts of repression demonstrated how little these parties were inclined to subject themselves to the rules of democracy. Still, the policies of the Communist resistance movements lacked a uniform pattern. While in Bulgaria and Vietnam the various non-Communist groups did not play a significant role in the Resistance, in Yugoslavia, Albania, Greece, and Poland the Communist and non-Communist guerrillas proved, by and large, incapable of cooperating with each other. In fact, armed clashes between the CPY and the Chetniks, or between ELAS and EDES, began as early as 1942-1943. ${ }^{35}$

\footnotetext{
${ }^{30}$ David H. Close, Greece since 1945: Politics, Economy, and Society (London: Pearson Education Limited, 2002), 13, 19-20.

${ }^{31}$ Mark Mazover, „The Cold War and the Appropriation of Memory: Greece after Liberation,” in The Politics of Retribution in Europe. World War II and Its Aftermath. Edited by Istvan Deak, Jan T. Gross, and Tony Judt (Princeton: Princeton University Press, 2000), pp. 214-215.

${ }^{32}$ Eagle Glassheim, ,National Mythologies and Ethnic Cleansing: The Expulsion of Czechoslovak Germans in 1945," in Central European History Vol. 33 (2000), No. 4, p. 475.

${ }^{33}$ Noskova, ,Migration of the Germans after the Second World War,” p. 105; Philipp Ther, Deutsche und polnische Vertriebene. Gesellschaft und Vertriebenenpolitik in der SBZ/DDR und in Polen 1945-1956 (Goettingen: Vandenhoeck \& Ruprecht, 1998), pp. 37, 49.

${ }^{34}$ Feher Istvan, A magyarorszagi nemetek kitelepitese 1945-1950 (Budapest: Akademiai Kiado, 1988), pp. 24-27.

${ }^{35}$ Ole L. Smith, ,'The First Round' - Civil War during the Occupation," in The Greek Civil War, 1943 1950. Studies of polarization. Edited by David H. Close (London: Routledge, 1993), pp. 60-65; Mark Wheeler, „Pariahs to partisans to power: the Communist Party of Yugoslavia," in Resistance and Revolution in Mediterranean Europe 1939-1948, pp. 132-136
} 
Characteristically, all six countries would experience some sort of civil war in 1944-1948. On the other hand, the Italian, Belgian, and Slovak partisan movements were based on the close cooperation of Communists and nonCommunists, which manifested itself in the creation of common organizations. ${ }^{36}$ Relations between the Gaullist AS and the Communist FTP proved cooler, but the French Resistance also managed to avoid internecine conflict. In addition to the essential difference betwen the „Italian” and the „Greek approach” (as the PCI put it at the end of $1944^{37}$ ), there were other dissimilarities as well. „With its broad patriotic and democratic programme during the occupation, EAM attracted professional people, including many army officers; some bishops with many parish priests; many shopkeepers; and some merchants and industrial employers. ${ }^{38}$ By contrast, at the end of 1941 and in the spring of 1942 the CPY pursued ultra-radical policies in Montenegro and Hercegovina, shooting 'kulaks,' desecrating churches, and planning the establishment of soviets and kolkozy. ${ }^{39}$

The absence of uniformity in wartime Communist resistance questions the validity of those interpretations which consider the policies of these parties simply the reflection of contemporary Soviet foreign policy. ${ }^{40}$ To be sure, Stalin did his best to create broad anti-Fascist alliances and guerrilla movements in every Nazi-occupied country, and he resurrected the idea of 'Popular Fronts' (renamed as 'National Fronts') in order to achieve this aim. Still, the conception worked less perfectly in certain countries than in others. In Yugoslavia, Greece, Albania, and Poland the Communist parties had been repressed in the interwar era, and their policies were regarded (not without justification) as opposed to the territorial integrity and national interests of the countries in question (see the conflicts over Greek Macedonia, Kosovo, Western Belarusia and Ukraine, and so on). The proximity of the USSR also gave cause for fears of Communist domination. The divisions these factors had created between Communist and non-Communist resistance movements could not be easily overcome by any new Soviet directive. By contrast, in Western Europe the CPs had profited

\footnotetext{
${ }^{36}$ See, among others, David W. Ellwood, Italy 1943-1945 (Leicester: Leicester University Press, 1985), pp. 76-79; Geert van Istendael, A belga labirintus, avagy a formatlansag baja (Budapest: Gondolat Konyvkiado, 1994), pp. 54-55; Eugen Steiner, The Slovak Dilemma (Cambridge: Cambridge University Press, 1973), pp. 51-63.

${ }^{37}$ Ellwood, Italy 1943-1945, p. 159.

${ }^{38}$ David H. Close, „Introduction,” in The Greek Civil War, 1943-1950, pp. 16-19.

${ }^{39}$ Ivo Banac, With Stalin against Tito. Cominformist Splits in Yugoslav Communism (Ithaca-London: Cornell University Press, 1988), pp. 81-82.

${ }^{40}$ See, among others, Eduard Mark, ,Revolution by Degrees: Stalin's National Front Strategy for Europe, 1941-1947." Cold War International History Project Working Paper No. 31 (February 2001), pp. 7-19.
} 
from parliamentary democracy and from the geographical distance between that region and the USSR. During World War II, as Alfred J. Rieber notes, the local Communist parties ,often took divergent paths not only from one another but even from the general line of the united front as Moscow defined it both in public announcements and in clandestine messages. At the end of the war the Foreign Department of the Central Committee was forced to acknowledge that contacts with foreign communist parties were wholly inadequate and had 'an episodic character'." ${ }^{41}$ The Soviets, on their part, seem to have laid a greater emphasis on the creation of successful partisan movements than on the establishment of effective National Fronts. Due to Soviet pressure, the Bulgarian Communists launched a guerrilla campaign in 1941, though they could not count on the support of non-Communist groups, and their activity did not prove particularly popular. ${ }^{42}$ „By the spring of 1942 the Yugoslav partisans were being held up as a model and all other resistance movements urged [by Moscow] to follow their lead," ${ }^{43}$ albeit their ultra-leftist policies were ,"completely out of tune with the Soviet position." 44

The Soviets, motivated by tactical and other considerations, often seem to have disagreed with the ultra-leftist ideas of certain CPs. For instance, in 1944 Moscow reproached the Polish and Bulgarian Communists for having taken „certain excessively radical measures" which might have jeopardized the aims of Soviet foreign policy. ${ }^{45}$ In the 1942-1948 period the Kremlin persistently warned Tito against pursuing ultra-leftist domestic and foreign policies, but most of its warnings went unheeded. ${ }^{46}$ The East German Communist leader Ulbricht ,wanted major show trials of Nazi capitalists, but the Soviets vetoed his idea, arguing that show trials would cause unnecessary turmoil among the Germans." ${ }^{47}$ The bloodless character of the North Korean land reform, which otherwise resembled Chinese Communist land reform campaigns, may also have resulted from Soviet directives. These episodes reveal that the subsequent repressive policies of the East European Stalinist regimes should not be regarded solely as the consequence of Soviet pressure, for many local Communist leaders

${ }^{41}$ Alfred J. Rieber, ,Soviet Planning for Post-War East-Central Europe," in CEU History Department Yearbook, 1997-1998. Edited by Eszter Andor, Andrea Peto, and Istvan Gyorgy Toth (Budapest: Central European University, 1999), pp. 78-79.

${ }^{42}$ Marshall Lee Miller, Bulgaria during the Second World War (Stanford: Stanford University Press, 1975), pp. 62-63, 195-200.

${ }^{43}$ Geoffrey Swain, „The Comintern and southern Europe, 1938-43,” in Resistance and Revolution in Mediterranean Europe 1939-1948, p. 39.

${ }^{44}$ Banac, With Stalin against Tito, 82.

${ }^{45}$ Mark, ,Revolution by Degrees,” pp. 20-22, 31-33.

${ }^{46}$ See, among others, Banac, With Stalin against Tito, pp. 9-42.

${ }^{47}$ Naimark, The Russians in Germany, p. 361. 
and cadres were more than ready to resort to such measures. On the other hand, the human losses caused by direct Soviet interventions often offset the (relative and temporary) moderation the Kremlin thrust down the throat of the East European Communist parties. According to official Soviet documents, 42,889 Germans (probably more) died in Sachsenhausen, Bautzen, and other concentration camps run by the Soviet occupation authorities. That is, more than a third of the internees lost their lives. ${ }^{48}$ Some 1,5 million people, over an eighth of the local population, were deported by the Soviet regime from newlyoccupied Western Ukraine and Western Belarusia, and at least 21,857 Poles were executed as a result of a Politburo resolution passed in March $1940 .{ }^{49}$ Approx. 600,000 Hungarians (370,000 POWs and 230,000 civilians) were taken to the Soviet Union in 1941-1945, of whom at least 180,000 died en route or in the GULAG. ${ }^{50}$ If a local Communist party lacked the necessary armed force, the Soviets often filled the gap. Since the Slovak guerrilla movement had been badly mauled by the Germans, it was the Soviet security service that arrested some 10,000 real and alleged supporters of the Tiso regime. ${ }^{51}$ Generally speaking, both partisan takeovers and direct Soviet interventions claimed more lives than the policies of the imposed Stalinist dictatorships.

The question of whether Stalin had planned the 'Communization' of the occupied East European countries from the outset has been the subject of many debates. A number of historians rightly point out that Soviet thinking on Germany lacked a consistent logic, and emphasize that Moscow initially wished continued cooperation with the Western powers. ${ }^{52}$ "Only after the proclamation of the Marshall Plan in June 1947 did they [the Soviet leaders] decide to consolidate their conquests" and establish Communist regimes in Eastern Europe, Vladislav M. Zubok says. ${ }^{53}$ Stalin, however, seems to have laid a greater emphasis on avoiding a confrontation with the West than on the preservation of democracy in East-central and South-east Europe - an important difference. Soviet foreign policy was thinking in spheres of interest, and since Stalin allowed the British

\footnotetext{
${ }^{48}$ Naimark, The Russians in Germany, pp. 376-378, 385-388.

${ }^{49}$ Stephen Wheatcroft, , The Scale and Nature of German and Soviet Repression and Mass Killings, 193045," in Europe-Asia Studies Vol. 48 (December 1996), Issue 8, p. 1344.

${ }^{50}$ Stark Tamas, ,Magyarorszag haborus embervesztesege,” in Rubicon Vol. 11 (2000), No. 103, p. 48.

${ }^{51}$ Stanislav J. Kirschbaum, A History of Slovakia. The Struggle for Survival (Houndmills-London: Macmillan Press Ltd., 1995), p. 226.

${ }^{52}$ See, among others, Vojtech Mastny, The Cold War and Soviet Insecurity: The Stalin Years (New York: Oxford University Press, 1996); Naimark, The Russians in Germany, pp. 9-10, 465-467; and Vladislav M. Zubok, ,Soviet Activities in Europe after World War II,” in Problems of Post-Communism Vol. 42 (September/ October 1995), Issue 5, pp. 3-8.

${ }^{53}$ Zubok, ,Soviet Activities in Europe after World War II,”p. 6.
} 
a free hand in Greece, he expected the Western powers to tolerate Soviet rule over Eastern Europe. „To ask whether Stalin pursued communist revolution in Europe or continued cooperation with his allies is to pose a false antinomy," Eduard Mark correctly notes. „He wanted both. ${ }^{\circ 4}$ Nevertheless, he overlooks that the term 'National Front' had a very different meaning in Western and Eastern Europe. Far from the protective umbrella of Soviet troops, the West European CPs were compelled to think in parliamentary politics. By contrast, the early repressive policies of the East European Communist parties may be regarded as an indicator of long-term Soviet goals, or at least a factor decisively influencing the outcome of events. As the saying goes: One cannot make eggs out of an omelette.

Following the bloody and indiscriminate purges of 1944-1945, it was less than likely that the Bulgarian Communists would respect the rules of democracy, and the persecution of AK members was hardly an auspicious start for Polish parliamentarianism. In occupied Germany the „most serious targets” of Soviet repression were not conservatives or ex-Nazis but Social Democrats, though the latter theoretically constituted a part of the anti-Fascist coalition. ${ }^{55}$ The existence of a 'genuine coalition' in Hungary did not prevent the Communistdominated political police from keeping a number of non-Communist ministers and under-secretaries under surveillance as early as November 1945. It arrested Demeny, the leader of a 'dissident' Communist movement, right after the liberation of Budapest. (He would be released only in October 1956.) ${ }^{56}$ While the Communist leadership had not been involved in the political murders committed in Gyomro, it successfully blocked every attempt to prosecute the perpetrators. ${ }^{57}$ It was only Czechoslovakia where the issue of the Marshall Plan seems to have produced a decisive effect on Communist policies. In 19451946 the Czechoslovak CP, satisfied with its dominance in the parliament, did not resort to blatantly anti-democratic measures. In November 1947, however, the security service 'revealed' a 'conspiracy' in order to weaken the positions of Slovakia's largest political group, the Democratic Party. ${ }^{58}$

By contrast, in Finland events took a different course from the very beginning. Finland was not occupied by the USSR, and in 1944 the Soviets did not support the establishing of ,a popular volunteer movement to expel the Germans. Thus

\footnotetext{
${ }^{54}$ Mark, „Revolution by Degrees,” pp. 5-7.

${ }^{55}$ Naimark, The Russians in Germany, pp. 386-387. 4-5.

${ }^{56}$ Gyarmati Gyorgy, „A politika rendorsege a Rakosi-korszakban,” in Rubicon Vol. 12 (2001), Issue 3, pp.

${ }^{57}$ Palasik Maria, „A gyomroi gyilkossagok es kovetkezmenyeik, 1945-46,” pp. 63-65.

${ }^{58}$ Kirschbaum, A History of Slovakia, pp. 229-230.
} 
there was no opportunity in Finland ... for the emergence of an anti-Fascist resistance front of the kind that led to Communist alliances with Social Democrats and the liberal bourgeoisie elsewhere among the warring countries of Europe." The trials of Ryti and other politicians held responsible for Helsinki's participation in World War II ended, despite Soviet interference, with sentences „much lighter than those passed in corresponding post-war political trials in both the East and the West." In contrast with Hungary or Romania, the Sovietdominated Allied Control Commission did not interfere with the Finnish media. The Finnish Communists gained a quarter of parliamentary seats in the 1945 election, and, thanks to their hold over the Ministry of the Interior, they managed to infiltrate the security service and the police. Nonetheless, the foundations of the democratic system remained essentially intact in the 1945-1947 period (as opposed to the East European countries, the army was beyond Communist control), which helps to explain why the radical elements of the party failed to stage a coup in 1948. Moscow, on its part, proved more interested in a SovietFinnish treaty than in a political upheaval in Finland..$^{59}$ Thus the fate of both Finland and Eastern Europe seems to have been decided as early as 19441945.

\section{High Noon: Eastern Europe in 1948-1953}

It is a widely held view that the wave of the East European party purges was triggered by the Soviet-Yugoslav conflict, and the repressive policies of these regimes simply duplicated the Soviet model. In other words, the main objective of the purges was the establishment of Soviet control over the local Communist parties. This interpretation is certainly reasonable, but it covers only a part of the truth. For instance, some East European party leaders and cadres were tried, or even executed, on fabricated charges well before 1948, the year of the StalinTito break..$^{60}$ On the initiative of Yugoslav advisers, the Albanian party leadership executed three prominent Communists (Lulo, Fundo, and Gjinishi) without trial as early as 1944; Lulo and Gjinishi had been a Youth League leader and a Politburo member respectively. ${ }^{61}$ In 1944 Gheorghiu-Dej accused Foris, then

\footnotetext{
${ }^{59}$ Osmo Jussila, Seppo Hentila, and Jukka Nevakivi, From Grand Duchy to a Modern State. A Political History of Finland since 1809 (London: Hurst \& Company, 1999), pp. 227-236, 245-249.

${ }^{60}$ Several standard works on Soviet-dominated East Europe, such as Zbigniew K. Brzezinski's The Soviet Bloc. Unity and Conflict (Cambridge [Mass.]-London: Harvard University Press, 1967), do not mention any East European party leader purged in the 1944-1947 period.

${ }^{61}$ George H. Hodos, Show Trials. Stalinist Purges in Eastern Europe, 1948-1954 (New YorkWestport-London: Praeger Publishers, 1987), pp. 6-7.
} 
the General Secretary of the Romanian Communist Party, of having been a police informant. As a consequence, Foris was replaced in the same year, and killed without trial in $1946 .{ }^{62}$ Between 1947 and 1952 the Yugoslav regime tried dozens of middle-level Communist officials, survivors of the Dachau and Buchenwald concentration camps, and executed 11 of them. The victims were subjected to torture in order to make them 'confess' that they had been agents of the Gestapo. At first it was the Soviet security service that provided Belgrade with a list of 'suspects,' but the Stalin-Tito conflict failed to put an end to the 'Dachau trials. ${ }^{63}$ Although the confrontation between Moscow and Belgrade certainly shaped the characteristics of the East European purges (this was particularly obvious in Czechoslovakia ${ }^{64}$ ), the latter often had indigenous roots as well.

Moscow's involvement probably extended the scope of the purges. From 1948 to 1953 Stalin played a decisive role in the selection of the victims, and it was the Soviet advisers who taught the East European security services how to organize show trials. Had the Soviets not participated in the purges, the victims may have been liquidated without trial (as it was the case in pre-1933 Mongolia and pre-1948 Albania). However, the relationship between the local dictators and the Soviet advisers was not based on the subordination of the former to the latter (as suggested by several authors). While the top Soviet leaders could give the 'little Stalins' instructions, the advisers could not. In Bulgaria Soviet advisers Trifonov, Chernov, Petrov, and Filatov did maintain a close control over the operation of the state security service, and they certainly had the power to issue orders to the officials of the Ministry of the Interior, but the country's supreme leader, Chervenkov, remained beyond their reach. For instance, in 1952 Chervenkov had Filatov, who had attempted to unseat Minister of the Interior Tsankov, recalled. ${ }^{65}$ In Hungary both Rakosi and the Soviet advisers (Belkin and Makarov) played a crucial role in the organization of the Rajk trial. When the Hungarian security organs proved incapable of extracting the required confession from Rajk, Belkin's team stepped in. Nevertheless, the Hungarian dictator insisted on participating in the creation of the indictment.

${ }^{62}$ Dennis Deletant, Communist Terror in Romania. Gheorghiu-Dej and the Police State, 1948-1965 (London: C. Hurst \& Co. Ltd., 1999), pp. 29-33, 151-153.

${ }^{63}$ Ivo Banac, With Stalin against Tito, p. 20; Bruno Heidlberger,

Jugoslawiens Auseinandersetzung mit dem Stalinismus. Historische Voraussetzungen und Konsequenten (Frankfurt-am-Main: Verlag Peter Lang, 1989), pp. 243-244.

${ }^{64}$ See, among others, Igor Lukes, ,The Rudolf Slansky Affair: New Evidence,” in Slavic Review Vol. 58 (Spring 1999), No. 1, pp. 172-173.

${ }^{65}$ Gospodinka Nikova, „The Blow against the State Leadership of Bulgaria (1949-1953),” in Bulgarian Historical Review Vol. 25 (1997), No. 2-3, pp. 116-126. 
„We bitterly argue with each other,” Belkin told Hungarian security chief Pйter. „He [Rakosi] always wants more and more. It is never enough. Now he even demands [to insert in the indictment] that Rajk wanted to kill Rakosi." ${ }^{\prime 66}$

In any case, the scale of repression was enormous everywhere in Eastern Europe. With regard to the institutions and the targets of the terror, the various dictatorships were rather similar. Still, certain regimes proved more oppressive than others. In these years no East European leader questioned the universal validity of Soviet experience, yet even the same policies, if applied on different societies, could yield different results. As opposed to their East German counterparts, the Czech Communists failed to create a new working-class intelligentsia, since in Bohemia and Moravia working-class children ,paid only half-hearted attention to high school admissions... In Poland, Bulgaria, or even Slovakia large numbers of peasants eagerly embarked upon higher education and moved into the growing cities. In the Czech Lands, that sort of social advancement had occurred generations earlier." ${ }^{\prime 67}$ It is also worth comparing the East European regimes with regard to the number of political prisoners. Between 1944-1945 and 1953, some 12,000 persons passed through Bulgarian labor camps. By contrast, in Poland 84,200 people (in proportion to the population, more than twice as many as in Bulgaria) had similar experiences between 1945 and 1954. While in Poland the number of imprisoned priests stood at about 100, the Czechoslovak dictatorship sent as many as 2,000 priests to labor camps. Both regimes imprisoned or interned prelates, such as Cardinal Wyszynski, Archbishop Beran, and bishops Kaczmarek and Trochta, whereas in East Germany no leading member of the Protestant church hierarchy went to prison. ${ }^{68}$ As opposed to Hungary, where the dictatorship of Rakosi arrested some 400 Social Democrats, in Gottwald's Czechoslovakia over 7,000 members of the Socialist Party were sentenced. In Hungary the number of political prisoners stood at 7,093 in 1953, while Czechoslovak jails had held some 25,000 'politicals' (proportionately, two and a half times as many as in Hungary) as

${ }^{66}$ „Rakosi Matyas, Rajk-per, Peter Gabor (Dokumentumok. Kozzeteszi: Zinner Tibor),” in Histyria Vol. 14 (1992), No. 5-6, pp. 58-59.

${ }^{67}$ John Connelly, ,Students, Workers, and Social Change: The Limits of Czech Stalinism,” in Slavic Review Vol. 56 (Summer 1997), No. 2, pp. 308-333.

${ }^{68}$ Elizabeth A. Clark, „Church-State Relations in the Czech Republic: Past Turmoil and Present Transformation," in Brigham Young University Law Review Vol. 1996 (1996), Issue 4, pp. 1019-1086; John S. Conway, „The'Stasi' and the Churches: Between Coercion and Compromise in East German Protestantism, 1949-1989," in Journal of Church \& State Vol. 36 (Autumn 1994), Issue 4, pp. 725-747; Andrzej Paczkowski, Fel evszazad Lengyelorszag tortenetebol 1939-1989 (Budapest: 1956-os Intezet, 1997), p. 171; Andrzej Paczkowski, „Poland, the 'Enemy Nation'," in The Black Book of Communism. Crimes, Terror, Repression (Cambridge [Mass.]-London: Harvard University Press, 1999), p. 382; Todorov, Voices from the Gulag, pp. $38-42$. 
early as $1949 .{ }^{69}$ These differences highlight the importance of local circumstances, the variety of Soviet guidelines, and the personal responsibility of the East European leaders. The adoption of the 'Soviet model,' while undoubtedly a decisive factor, does not explain every aspect of East European repression.

The East European dictatorships did not copy the Soviet machinery of terror in every respect, though the similarities remained substantial enough. For instance, in the Soviet Union and Hungary 'de-kulakization' affected some one million and 72,000 families respectively. That is, the number of 'kulaks' in relation to the population proved somewhat higher in Hungary (a country of 9,205 million inhabitants in 1948) than in the USSR. ${ }^{70}$ On the other hand, the similar number of targets was not necessarily accompanied by similar methods of repression. In Hungary the total number of prisoners sentenced by civilian and military courts, or interned by the authorities, stood at 41,639 on 1 April 1953, whereas in mid-June there were 7,093 political and 24,498 other prisoners in the country. That time, Hungarian internment camps held 5,036 inmates. ${ }^{71}$ By contrast, in January 1939 there were slightly over two million prisoners (in relation to the population, two and a half times as many persons) in Soviet prisons, concentration camps, and forced labor colonies. Camp inmates constituted some three-fifths of that figure, indicating that labor camps played a much more important role in the USSR than in Hungary. Due to frequent transfers to the GULAG, the Soviet prison population remained much less constant within a year than its Hungarian counterpart. By contrast, both the Hungarian prison population and the number of persons held in the GULAG grew steadily. ${ }^{72}$ In 1950-1951 the Hungarian dictatorship deported 16,044 persons from the capital and the southern border region, whereas the number of individuals the Soviet regime had exiled as 'kulaks' was 1,803,392. That is, the Soviet deportations of 1930-1931 alone affected, in proportion to the population, six times as many persons as the Hungarian ones. Moreover, at least 240,000 Soviet exiles died in 1932-1933 - a death rate incomparably higher than its Hungarian counterpart. ${ }^{73}$

\footnotetext{
${ }^{69}$ Karel Bartosek, „Central and Southeastern Europe,” in The Black Book of Communism, p. 405; Lukes, „The Rudolf Slansky Affair: New Evidence,” p. 164; Punkosti Arpad, Rakosi a csucson 1948-1953 (Budapest: Magyar Konyvklub, 1996), p. 293; Zinner Tibor, XX. szazadi politikai perek. A magyarorszagi eljarasok vazlata 1944/45-1992 (Budapest: Rejtjel Kiado, 1999), pp. 38-40.

${ }^{70}$ Punkosti Arpad, Rakosi a csucson 1948-1953, p. 455; Lynne Viola, Peasant Rebels under Stalin. Collectivization and the Culture of Peasant Resistance (New York-Oxford: Oxford University Press, 1999), p. 86.

${ }^{71}$ Zinner Tibor, XX. szazadi politikai perek, pp. 38-40.

${ }^{72}$ Viktor Zemszkov, „A Gulag tenyekben, adatokban,” in Gulag. A szovjet taborrendszer tortenete. Szerk. Krausz Tamas (Budapest: Pannonica Kiado, 2001), p. 227.

${ }^{73}$ Punkosti, Rakosi a csucson 1948-1953, pp. 274, 397; Nicolas Werth, „A State against its People: Violence, Repression, and Terror in the Soviet Union," in The Black Book of Communism, pp. 153-155.
} 
The most significant difference between Soviet and East European Stalinist repression manifested itself in the number of executions. In Hungary some 500 individuals were executed for political reasons in the 1946-1956 period. From 1945 to 24 February 1951, 227 executions took place. Of the 227 persons in question, 146 had been sentenced for war crimes and crimes against humanity. While some of the latter verdicts lacked a proper justification, others did not. ${ }^{74}$ The scale of executions proved quite similar in the other East European countries: 178 in Czechoslovakia between October 1948 and the end of 1952, 137 in Romania from 1945 to 1964, and 20 in Poland between 1950 and 1953. ${ }^{75}$ These figures, in relation to the respective populations, were lower than the annual average (approx. 1650-1700) of Soviet political executions in the 19321936 and 1943-1953 periods, to say nothing of the Great Terror that led to the execution of 681,692 individuals in two years. ${ }^{76}$ Significantly, the powers of the Hungarian political police did not include the right to mete out death sentences, though it could intern people (including persons acquitted by courts) at will. ${ }^{77}$ By contrast, in the USSR 92,6 per cent of the death sentences handed down in 1937-1938 were passed by troiki, that is, without usual judicial procedure. ${ }^{78}$ In Hungary a decree passed in May 1945 authorized People's Courts to sentence persons over 16 to death, whereas in April 1935 the Soviet Politburo had extended the death penalty to ,young criminals, from the age of 12 upward." 79 In addition, the CPSU suffered much heavier losses due to the purges than its Hungarian counterpart. Of the 1,5 million people arrested in 19371938, some 122,000 had belonged to the party. In Leningrad over 90 per cent of the party cadres were arrested ${ }^{80}$ By contrast, the total number of Hungarian Communist and Social Democratic party members affected by the political trials did not exceed 430, that is, one per cent of those sentenced for political reasons in the 1946-1956 period. $^{81}$

\footnotetext{
${ }^{74}$ Laszlo Karsai, ,,The People's Courts and Revolutionary Justice in Hungary, 1945-46,” in The Politics of Retribution in Europe, p. 233; Zinner, XX. szazadi politikai perek, pp. 31-34.

${ }^{75}$ Deletant, Communist Terror in Romania, pp. 133-143; The Czechoslovak Political Trials 1950-1954. The Suppressed Report of the Dubcek Government's Commission of Inquiry, 1968. Edited with a preface and a postscript by Jiri Pelikan (Stanford: Stanford University Press, 1971), p. 56; Paczkowski, Fel evszazad Lengyelorszag tortenetebol 1939-1989, p. 177.

${ }^{76}$ Nicolas Werth, „Deportalas, Gulag, ehinsegek. A Szovjetunio, avagy a terror uralma,” in Rubicon Vol. 12 (2001), Issue 4-5, p. 19.

${ }^{77}$ Zinner, XX. szazadi politikai perek, pp. 31-34.

${ }^{78}$ Getty and Naumov, The Road to Terror, p. 470.

${ }^{79}$ Francesco Benvenuti, ,The 'Reform' of the NKVD, 1934,” in Europe-Asia Studies Vol. 49 (1997), No. 6, p. 1048; Zinner, XX. szбzadi politikai perek, pp. 31-34.

${ }^{80}$ Gabor T. Rittersporn, „A terror,” in Rubicon Vol. 12 (2001), Issue 4-5, p. 33.; Werth, „A State against its People," p. 192.

${ }^{81}$ Zinner, XX. szбzadi politikai perek, pp. 31-34.
} 
The relative ,mildness” of the East European dictators by no means stemmed from any fundamental difference between Stalin's worldview and theirs. These leaders were as inclined to believe in the ubiquitousness of the 'enemy' as the Soviet tyrant had been. By 1953 the Polish political police had files on a third of the adult population. ${ }^{82}$ In 1951 the Bulgarian regime arrested almost all military generals (the majority of them would be released before Stalin's death, however). ${ }^{83} \mathrm{~A}$ Hungarian investigation carried out in 1949 concluded that some 40 per cent of state security officers, who had played an indispensable role in the establishment of the regime, were 'unreliable.' Commenting on the high percentage of 'unreliable elements' among lower-level state and party cadres, Rakosi grumbled: „We have inherited such a proletariat... the whole population must be remoulded. Only a small part of it can be put in prison." ${ }^{84}$ The post1948 East European dictatorships did not resort to mass executions in order to deal with that alleged 'threat,' however. By contrast, as indicated before, the Choibalsan regime had slaughtered tens of thousands in a country of less than one million inhabitants. Had Rakosi carried out a comparable purge, he would have executed over 100,000 people. The difference is all the more striking since both the Mongolian and the East European regimes were closely controlled by Moscow.

One may explain that obvious dissimilarity by highlighting the peculiarity of Mongolian and Russian political traditions. In fact, East European traditions may have played a certain role in the absence of mass executions. Rakosi kept saying that had Hungary had a Siberia, it would have been much easier to liquidate the 'class enemy. ${ }^{85}$ It is also significant that the purge of 'Cominformists,' carried out by the Tito regime in 1948-1951, rarely resulted in liquidations, though most of the sentences had been passed by the security service instead of regular civilian or military courts ${ }^{86}$ Nevertheless, it should be pointed out that neither Stalin nor Choibalsan returned to the policy of mass slaughter in the post-1945 years. The number of Soviet political executions underwent a sharp decline after the Great Terror (from 328,618 in 1938 to 2,552 in 1939). Between 1943 and 1953 the annual average of such executions was not significantly higher than in the 1932-1936 period (and it was lower than in the period between 1921 and 1929), though several prominent party leaders (Voznesensky, Kuznetsov, Rodionov, Soloviev, and others) perished in

\footnotetext{
${ }^{82}$ Paczkowski, ,Poland, the 'Enemy Nation',” p. 382.

${ }^{83}$ Nikova, ,The Blow against the State Leadership of Bulgaria (1949-1953),” pp. 125-126.

${ }^{84}$ Punkosti, Rakosi a csucson 1948-1953, pp. 120, 370.

${ }^{85}$ Ibid., p. 235.

${ }^{86}$ Banac, With Stalin against Tito, pp. 121, 245-247.
} 
Stalin's postwar purges. A possible explanation is that the repressive policies of the satellite regimes more or less followed the dynamic of Soviet executions. The exceptional severity of the Mongolian purges had resulted from their coincidence with the Great Terror, while the East European dictatorships' model was Stalin's post-1945 'selective repression' (that is, the execution of highranking leaders was not accompanied by the mass slaughter of cadres and ordinary citizens). In other words, the East European regimes did not duplicate each stage of development the USSR had gone through between 1927 and 1953 but copied a particular form of Stalinism. This seems to indicate that Stalin, as suggested by Gбbor T. Rittersporn, sometimes proved capable of learning from his blunders.

According to Rittersporn, the Soviet leadership recognized that the mass executions of 1937-1938 had failed to solve any political or economic problem. ${ }^{87}$ While this interpretation may not be completely correct, it is worth recalling a conversation that took place between Stalin and Chervenkov in January 1951. The Soviet dictator ,advised the Bulgarian leaders not to carry out a dispossession of the kulaks, not to copy blindly the Soviet experience of the 30 s and to artificially heighten the tension in the country." ${ }^{\prime 88}$ (As a consequence, Sofia would temporarily slacken the pace of collectivization.) Significantly, both the East European and the Asian Communist dictatorships carried out the collectivization of agriculture in several stages. At first peasants were grouped into lower-level (Type I) cooperatives, then into intermediate (Type II) ones, and finally into higher-level (Type III and IV) farms. ${ }^{89}$ This had not been the case in the Soviet Union, however. In 1929 the Soviet regime did not give its cadres exact instructions on how to establish co-ops; the main goal of this strategy may have been ,to get local cadres pushing for the absolute maximum, thus providing both quick results and information on what the attainable maximum actually was." ${ }^{90}$ The various negative experiences gained in these years seem to have convinced Stalin of the advantages of gradualism. Thus it is not impossible that the Great Terror was also critically re-examined by the Soviet dictator. To be sure, neither the practice of political executions nor the

\footnotetext{
${ }^{87}$ Rittersporn, „A terror,” p. 33.

${ }^{88}$ Vladimir Migev, „The Bulgarian Peasants' Resistance to Collectivization (1948-1958),” in Bulgarian Historical Review Vol. 25 (1997), Issue 1, pp. 62-63.

${ }^{89}$ See, among others, Karl-Eugen Waedekin, Agrarian Policies in Communist Europe. A Critical Introduction (The Hague-London: Allanheld, Osmun and Martinus Nijhoff, Publishers, 1982), pp. 38-39; Dali L. Yang, Calamity and Reform in China. State, Rural Society, and Institutional Change Since the Great Leap Famine (Stanford: Stanford University Press, 1996), pp. 24-31.

${ }^{90}$ Sheila Fitzpatrick, Stalin's Peasants. Resistance and Survival in the Russian Village after Collectivization (New York-Oxford: Oxford University Press, 1994), pp. 49-50.
} 
maintenance of labor camps came to an end. Both forms of repression would be also characteristic of the East European regimes. Therefore, one may conclude that the latter methods constituted a more integral part of Stalinism than the Great Purges. The mass terror of 1937-1938 was not necessarily a logical consequence of 'Bolshevik mentality.' Political paranoia was as widespread in Eastern Europe as it had been the Soviet Union, yet the witch-hunt carried out by the 'little Stalins' did not culminate in the execution of tens of thousands. However, this fact highlights, rather than diminishes, Stalin's personal responsibility for the Great Terror.

\section{A Case Study: North Korea}

As Bruce Cumings points out, the North Korean dictatorship of Kim Il-sung has been (and still is) frequently characterized as an Asian copy of Soviet Stalinism. ${ }^{91}$ True, Soviet influence on the development of North Korean political and judicial institutions was substantial in the first decade of the regime. For instance, the Hungarian diplomats accredited to the DPRK found the structure of the North Korean judicial organs (the Ministry of Justice, the Supreme Public Prosecutor's Office, and so on) very similar to that of Hungarian ones. They also noted that the North Korean criminal code had been written with the help of Soviet advisers. Paradoxically, this dependency on Soviet expertise partly resulted from the nationalist stance of the Kim Il-sung regime. Although P'yongyang initially retained certain Japanese laws and many Japanese-trained judges, ${ }^{92}$ the purge of 'pro-Japanese elements' proved thorough enough. (By contrast, the South Korean regime of Syngman Rhee continued to employ large numbers of Japanese-trained police officers and officials.) In the mid-1950s the extreme paucity of trained judges and attorneys still constituted a serious problem. In the post-liberation period many 'politically reliable workers' had been appointed judges on the grounds that they would simultaneously receive legal training through evening classes. Thus it was quite understandable that the regime turned to the Soviets for legal expertise, though Korean traditions also influenced North Korea's constitution, criminal code, and legal system. As the Hungarian diplomats noted in 1954, the authorities did not reckon the beginning of one's life from his birth (as it is the case in Europe) but from his

\footnotetext{
${ }^{91}$ Bruce Cumings, The Origins of the Korean War II. The Roaring of the Cataract (Princeton: Princeton University Press, 1990), pp. 291-294.

${ }^{92}$ Charles K. Armstrong, ,Surveillance and Punishment in Postliberation North Korea," in East Asia Cultures Critique Vol. 3 (Winter 1995), No. 3, pp. 701-703.
} 
conception; that is, a person born twenty years ago was officially registered as twenty-one years old. The limited financial resources of the North Korean state sometimes retarded, rather than facilitated, the adoption of Soviet-style institutions, and compelled the country's rulers to seek alternative solutions. For example, the unpaid self-defence and security forces P'yongyang established in every village had no counterparts in most East European countries. ${ }^{93}$

In North Korea the creation of a monolithic political structure was a particularly rapid process. Like in the three South-east European countries, Communist dominance had become undisputed by 1946. A governmentcontrolled Federation of Trade Unions came into existence as early as 30 November 1945, some two months after liberation. In January 1946 the North Korean authorities merged the various youth leagues into a single organization, while similar events would take place in Hungary only three years later. The membership of this new organization was proportionally far greater than that of the Komsomol. It had an unitary structure, while North Vietnam and China established two youth leagues, one for devout Communists and another for sympathizers. With the possible exception of Tito's Yugoslavia, nowhere in Europe did a leadership cult emerge as quickly as in North Korea. In 1946 the regime named the country's sole university for Kim Il-sung, and next year it set up schools for the orphans of revolutionary martyrs in Man'gyongdae, the dictator's home village. By contrast, Rakosi, though hardly an opponent of personality cult, never took comparable measures. Interestingly enough, the quick establishment of one-party and one-man rule was not necessarily accompanied with the similarly rapid adoption of Soviet economic policies. As opposed to Eastern Europe, no agricultural collectivization took place in the DPRK before 1953-1954, because P'yongyang did not want to alienate South Korean public opinion. ${ }^{94}$ In other words, North Korea overtook most East European regimes in the political field, but it lagged behind with regard to collectivization. Since the Mongolian Communist regime (and its Soviet backers) also placed greater emphasis on political monolithism than on economic transformation, one may conclude that the political and economic components

\footnotetext{
${ }^{93}$ Hungarian Embassy to the DPRK, Report, 12 December 1955, KTS, 6. doboz, 5/cb, 00603/1956; Hungarian Embassy to the DPRK, Report, 12 July 1954, KTS, 6. doboz, 5/d, 00868/1/1954; Hungarian Embassy to the DPRK, Report, 19 April 1953, XIX-J-1-k [Administrative Documents] Korea 1945-1964 [henceforth KA], 4. doboz, 5/cg, 04629/1/1953.

${ }^{94}$ Hungarian Embassy to the DPRK, Report, 23 October 1958, KTS, 12. doboz, 27/a, 006458/1958; Hungarian Embassy to the DPRK, Report, 27 October 1951, KA, 9. doboz, 18/g, 01939/1952; Hungarian Embassy to the DPRK, Report, 7 October 1953, KA, 6. doboz, 12/a, 011216/1953; Hungarian Embassy to the DPRK, Report, 29 November 1956, KA, 6. doboz, 12/a, 1/25-5/1957; Hungarian Embassy to the DPRK, Report, 19 July 1952, KTS, 3. doboz, 4/bc, 001024/2/1952.
} 
of the Soviet model were relatively loosely connected with each other. Nonetheless, this flexibility also meant (as indicated earlier) that the absence of overt 'Communization' was not a guarantee for political pluralism unless the Communist parties proved willing to observe the rules of democracy. The policies of the East German and North Vietnamese regimes also included the temporary postponement of certain unpopular economic measures so as to facilitate national unification, but such considerations did not prevent Pankow and Hanoi from stamping out any meaningful opposition.

In contrast with most East European countries, the 1948 purge of O Ki-sop and other North Korean 'domestic Communists' did not result in show trials which might have produced a negative effect on South Korean public opinion. (The Ulbricht regime similarly refrained from staging such trials in order not to jeopardize the cause of German unification.) The outcome of the largest shake-up the Korean Workers' Party experienced in Stalin's lifetime also differed substantially from that of the East European purges. The 3rd CC plenum, held in December 1950, launched a campaign against party members who had behaved passively under the brief period of US and South Korean occupation. Of the 700,000 KWP members, some 500,000 were disciplined. Kim Il-sung expelled a number of generals and other high-ranking officers from the Korean People's Army for 'defeatism,' i.e. for highlighting US superiority in the air. The purge did not spare the Kapsan faction, Kim Il-sung's trusted lieutenants, either. At the 3rd plenum the dictator personally pointed out how many 'crimes' Kim Il had committed, and several other influential Kapsan men were also relieved of their positions. Most probably, it was the very magnitude of the purge that led to a development not characteristic of the 1948-1953 policies of the East European 'people's democracies ${ }^{\prime 95}$ but usually associated with de-Stalinization. At the 4th CC plenum, held in November 1951, the leadership officially condemned 'leftist deviations,' and readmitted some 30 per cent of the expelled party members. Realizing that he had gone into overdrive, Kim Il-sung blamed the 'excesses' on his chief Soviet Korean rival, Ho Ka-i. With the notable exception of Mu Chong, the leaders purged in December 1950 were reinstated..$^{96}$

\footnotetext{
${ }^{95}$ In the Soviet Union, following the CC plenum held in June 1936, ,substantial numbers of expelled rankand-file members were readmitted on appeal. But most were not." Getty and Naumov, The Road to Terror, p. 240. As opposed to the North Korean case, demoted high-ranking Soviet leaders were usually unable to regain their lost positions.

${ }^{96}$ Hungarian Embassy to the DPRK, Report, 22 October 1952, KA, 11. doboz, 27/a, 012603/1952; Hungarian Embassy to the DPRK, Report, 21 March 1953, KTS, 5. doboz, 5/c, 00338/2/1953; Hungarian Embassy to the DPRK, Report, 8 June 1961, KTS, 13. doboz, 27/e, 003643/1/1961. See also Robert A. Scalapino and Chong-sik Lee, Communism in Korea II. The Society (Berkeley: University of California Press, 1972), pp. 456-457; Dae-Sook Suh, Kim Il-sung. The North Korean Leader (New York: Columbia University Press, 1988), pp. 122-126.
} 
Paradoxically, the only classical show trial the North Korean leadership has ever staged took place after Stalin's death. Nevertheless, the trial of Yi Sungyop and other party leaders of South Korean origin seems to have been organized with the assistance of Soviet, or at least Soviet-trained, security officers. In contrast with the 1950-1951 shake-up, but similarly to the events which had happened in Bulgaria, Hungary, and Czechoslovakia in 1948-1952, the purge did not strike the principal targets first but evolved gradually. Its first victim, the poet Yim Hwa was arrested in the fall of 1952. He may have been chosen for a role similar to the one Kiril Slavov, Noel Field, and Tibor Szxnyi had had to play in Sofia and Budapest respectively. That is, his interrogators used his forced confessions to implicate high-ranking party leaders in the 'plot' he had allegedly concocted. At the 5th CC plenum, held in December, Kim Il-sung made an attack on 'factional elements.' In the winter of 1952-1953 the purge swept various ministries, and in the spring of 1953 it was extended to the Youth League. On January 26th Foreign Minister Pak Hon-yong, the head of the South Korean Workers' Party, was interrupted and corrected by his deputy, Yi Tonggon in the presence of foreign diplomats, indicating the former's coming demotion. In March Kim Il-sung had Yi Sung-yop and other SKWP leaders arrested. Their trial took place in August, while Pak Hon-yong, also arrested in March 1953, was executed as late as 1955. Thus the framework of the purge did not differ much from the East European show trials, but it still had a Korean touch. The dividing line between East European 'domestic Communists' and their 'Muscovite' rivals proved more blurred than the one between South and North Korean Communists. For instance, North and South Korean Communist writers fiercely quarreled over the issue of standard language. While the first group intended to base standard Korean on the P'yongyang dialect, the second favored the Seoul dialect. These debates had become so embittered, the Hungarian diplomats noted, that writers of southern origin were most unwilling to accept any novel written by a northern author as a literary work, and vice versa. Thus the victims of the 1952-1953 purge belonged to a rather identifiable group, whereas the ties between Trotsky and Bukharin had existed merely in the imagination of Stalin and Vyshinsky. ${ }^{97}$

By 1956 Kim Il-sung had already purged several of his influential Soviet and Yan'an Korean rivals (Mu Chong, Ho Ka-i, Pak Il-u, and others), and in

\footnotetext{
${ }^{97}$ Hungarian Embassy to the DPRK, Report, 20 March 1953, KTS, 10. doboz, 24/b, 00808/1953; Hungarian Embassy to the DPRK, Report, 21 March 1953, KTS, 5. doboz, 5/c, 00338/2/1953; Hungarian Embassy to the DPRK, Report, 30 April 1953, KA, 11. doboz, 27/a, 04648/2/1953; Hungarian Embassy to the DPRK, Report, 15 April 1954, KTS, 4. doboz, 5/a, 00866/1954. See also Brian Myers, Han Sorya and North Korean Literature. The Failure of Socialist Realism in the DPRK (Ithaca: Cornell University, 1994), pp. 84-85.
} 
1957-1959 he broke the power of both factions once and for all. The function and importance of the latter campaign was comparable to the attack Stalin had launched on the intra-party opposition in 1926-1928, and even to the Great Terror of 1937-1938, but its methods proved rather different. First of all, the number of party members expelled between July 1957 and July 1958 did not exceed 4,000 , i.e. less than one per cent of the total membership. ${ }^{98}$ By contrast, the Soviet proverka of 1935 had resulted in the expulsion of 9,1 per cent of party members. ${ }^{99}$ On the other hand, the enforced participation of the whole membership in the screening process certainly filled each KWP member with fear and a sense of insecurity. While Soviet proverki and chistki had been carried out by the party committees and the security organs, in the DPRK party members, assembled in groups, had to practise criticism and self-criticism. If a person proved unable to name two witnesses testifying that he had not been involved in any anti-regime acivity since the outbreak of the Korean War, his self-criticism would not be accepted. Since one was prohibited from naming relatives, friends, or acquaintances as his witnesses, the psychological pressure thus created became extremely intense. In the second half of 1958 the regime purged the provincial party committees and People's Committees, replacing most of their chairmen, and at the end of the year it organized a public trial in each province. The courts usually meted out death sentences (executions were also public), and in some cases the incited audience beat the accused unconscious. ${ }^{100}$

The methods enumerated above had more in common with Maoist practices than with Soviet Stalinism. Nevertheless, the events that happened in North Korea between 1957 and 1969 had a logic somewhat similar to that of the Soviet purges of 1926-1938. In March 1959, following the campaign against the 'foreign' factions, the KWP was headed by a chairman (Kim Il-sung) and three deputy chairmen (Pak Chong-ae, Pak Kum-ch'ol, and Kim Ch'ang-man). Not counting Kim Il-sung, the Politburo was composed of nine full members (Ch'oe Yong-gon, Pak Chong-ae, Kim Il, Pak Kum-ch'ol, Chong Il-yong, Yi Hyo-sun, Yim Hae, Nam Il, and Kim Kwang-hyop) and four deputy members (Yi Chong-ok, Han Sang-du, Kim Ik-son, and Ha Ang-ch'on). ${ }^{101}$ These persons had faithfully supported Kim Il-sung vis-a-vis the Soviet and Yan'an factions, yet only Ch'oe Yong-gon and Kim Il managed to keep their positions by 1970 . The twelve others had been purged during the 1960s, some of them temporarily,

\footnotetext{
${ }^{98}$ I would like to thank Dr. Andrei N. Lankov for this piece of information.

${ }^{99}$ Getty and Naumov, The Road to Terror, p. 198.

${ }^{100}$ Hungarian Embassy to the DPRK, Annual Report, 24 February 1959, KTS, 4. doboz, 5/a, 002242/ 1959; Hungarian Embassy to the DPRK, Report, 4 June 1959, KTS, 5. doboz, 5/ca, 003047/1/1959.

${ }^{101}$ Hungarian Embassy to the DPRK, Report, 30 March 1959, KTS, 5. doboz, 5/ca, 002821/1959.
} 
some for good. By contrast, from the 1970s on Kim Il-sung would rarely purge Politburo members. ${ }^{102}$ Similarly, the chistki which took place in the Soviet Union in the 1930s removed a substantial part of the cadre generation that had supported Stalin in his 1926-1928 campaign against the intra-party opposition. The terror peaked in 1937-38, and the number of executions, though it would remain quite high until 1953, fell dramatically thereafter. One possible interpretation of these events is that both dictators wanted to get rid of the cadres whom they were indebted to for the latter's previous support. Having replaced this layer of the elite with another that was wholly dependent on them, they may have concluded that certain repressive measures were no longer necessary.

In other respects, however, the replacement of „old” leaders by „new” ones seems to have had a different logic in the two countries. The persons Kim trusted most were the Korean members of the so-called $88^{\text {th }}$ Brigade, i.e., those Manchurian guerrillas who spent WW II in the USSR with him, such as Ch'oe Yong-gon, Kim Il, Pak Song-ch'ol, Ch'oe Hyon, and O Chin-u. Very few of them were removed for good, and from 1970 on they constantly dominated the top party leadership. The next circle was made up of those men who had also been associated with the Manchurian guerrilla movement but did not belong to the $88^{\text {th }}$ Brigade, like Pak Kum-ch'ol, Sok San, Kim Kwang-hyop, and Ho Bonghak. They also enjoyed a privileged position, but a quite high number of them fell victim to the purges of 1967-1969. (By contrast, certain technocrats, such as Chong Chun-t'aek, were consistently spared, but they never became as influential as the members of the first circle.) The third circle was made up of those Soviet, Yan'an, SKWP, and ,domestic" leaders who took sides with Kim Il-sung against the leaders of their factions, like Pang Hak-se, Nam Il, Kim Ch'ang-man, and Ha Ang-ch'on. Partly due to the twists and turns of North Korean foreign policy, their influence gradually declined after 1959, and some of them were even purged. In the first years of Kim's rule, former guerrillas constituted only a quite small minority of the party leadership. By 1956, they had become the strongest group, and in 1961 they already formed the majority. Nonetheless, the positions of former Brigade members were still relatively weak: of the twenty highest-ranking CC members, only three and five (including Kim himself) belonged to that group in 1956 and 1961 respectively. By 1970 the ex-guerrillas had become absolutely dominant, and of the top ten CC seats, as many as seven were occupied by former Brigade members and the eighth was

${ }^{102}$ Adrian Buzo, The Guerilla Dynasty. Politics and Leadership in North Korea (London-New York: I.B. Tauris Publishers, 1999), pp. 53, 83. 
held by Kim Yong-ju, the dictator's younger brother. ${ }^{103}$ From that time on, Politburo purges noticeably abated: in 1994, when Kim Il-sung died, ,,it had been seventeen years since the purge of Vice President Kim Tong-gyu in October 1977 - the last sudden, unexplained disappearance from public view of a senior cadre." 104 That is, Kim Il-sung first reinforced the position of the ex-guerrillas at the expense of all other groups, then ensured the dominance of former Brigade members over other guerrillas. Having achieved this aim, the dictator did not initiate any new large-scale shake-up. In addition, some leaders who lost their Politburo membership in the 1960s, such as Yim Ch'un-ch'u and Yi Chong-ok, were reappointed in the 1970s.

The Soviet counterpart of the $88^{\text {th }}$ Brigade was probably the „Stalinist kernel” (a term coined by Graeme Gill), namely, Molotov, Kaganovich, Voroshilov, Mikoian, Andreev, and the basically powerless Kalinin. These men consistently supported Stalin at least from the mid-1920s on, and they managed to survive every purge the dictator carried out. With the exception of Kalinin, who died of illness, they actually outlived Stalin. However, the position of this group was quite different from that of the $88^{\text {th }}$ Brigade. While the latter's members, with very few exceptions, occupied only relatively marginal positions in the first decade of Kim Il-sung's rule and their obvious dominance began as late as twenty-five years after Kim had assumed the party's leadership, the men who constituted the „Stalinist kernel” had joined the Politburo as early as before July 1926. In other words, the Soviet purges which took place in the 1930s cannot be regarded as a prerequisite for placing this group in the top leadership. While the victims of the pre-1970 North Korean purges belonged to groups which had come into existence before 1946, many of the CPSU Politburo and CC members executed in 1937-1940, like Kosior, Chubar, Bauman, Rudzutak, Postyshev, Eikhe, and Ezhov, had nothing to do with the groups Stalin had subdued in 1923-1929. On the contrary, they often played an active role in the struggle against the aforesaid factions, and they owed their advancement entirely to the dictator. Still, they proved particularly vulnerable. Of the ten men who joined the Politburo between July 1926 and 1939, only two survived. ${ }^{105}$ An even more junior cohort of party leaders, namely, the CC members elected for the first time in 1934, was also hit hard. Of them, only 21 per cent were reelected in 1939. In the post-1945 era Stalin began to take steps to undermine

\footnotetext{
${ }^{103}$ Sung Chul Yang, The North and South Korean Political Systems. A Comparative Analysis (Boulder, Westview Press, and Seoul, Seoul Press, 1994), pp. 339-341.

${ }^{104}$ Buzo, The Guerilla Dynasty, p. 53.

${ }^{105}$ Graeme Gill, The Origins of the Stalinist Political System (Cambridge: Cambridge University Press, 1990), pp. 285-286.
} 
the positions of Molotov and Andreev, but his last purges also affected, either directly or indirectly, those men who had joined the top leadership after the Great Terror, such as Voznesensky and Beria. Thus the potential of eventual consolidation seems to have been weaker in Stalin's USSR than in Kim Ilsung's North Korea, though in 1939-1952 the attrition rate of the CPSU CC was certainly much lower than it had been in 1930-1939. ${ }^{106}$ One may also point out that Soviet Politburo members demoted by Stalin, in contrast with some KWP leaders, proved unable to regain their lost posts in the dictator's lifetime.

The North Korean regime operated in a sociopolitical environment quite different from Soviet or, say, Hungarian society, and its policies often intensified these differences. From the very beginning, Kim Il-sung did his best to create a mass party, recruiting hundreds of thousands of peasants into the North Korean Workers' Party. The proportion of peasants was much higher in the NKWP than in the CPSU. ${ }^{107}$ One factor facilitating the rapid expansion of the party's rural basis was that apart from Ch'ondoggyo believers, the Korean political scene lacked a mass-based, non-Communist peasant party comparable to the influential Russian, Ukrainian, Polish, Czech, Slovak, Hungarian, Croatian, Romanian, and Bulgarian agrarian parties. In this respect North Korea proved more similar to China and North Vietnam than to Russia and Eastern Europe. While in Russia the majority of the Bolshevik Party's rural supporters had been recruited from the younger generations which , challenged the authority of their peasant elders," 108 in the mid-1950s the rural organizations of the KWP were often headed by the oldest, most thoughtful male members of the village communities. ${ }^{109}$ This combination of traditional and Communist leadership, which was also widespread in clan-based 'leftist villages' in South Korea, ${ }^{110}$ had a lot in common with the composition of Central Asian rural CPSU organizations. In 1928 „Turkmen village cells were usually dominated by aksakgals (,white beards," or elders) - well-off and influential local leaders."111 On the other hand, the North Korean Youth League, like its Soviet, Chinese, and North Vietnamese counterparts, played a decisive role in the collectivization

106 T. H. Rigby, „Was Stalin a Disloyal Patron?,” in Articles on Russian and Soviet History 1500-1991. VII. Stalin and Stalinism, ed. by Alexander Dallin (New York and London: Garland Publishing, Inc., 1992), pp. 117-124.

${ }^{107}$ Cumings, The Origins of the Korean War II, 299-302.

${ }^{108}$ Orlando Figes, A People's Tragedy. The Russian Revolution 1891-1924

(London: Pimlico, 1997), pp. 790-792.

${ }^{109}$ Hungarian Embassy to the DPRK, Report, 6 December 1954, KTS, 12. doboz, 27/a, 001131/1955.

${ }^{110}$ Cumings, The Origins of the Korean War II, pp. 248-249.

${ }^{111}$ Adrienne L. Edgar, ,Genealogy, Class, and Tribal Policy in Soviet Turkmenistan, 1924-1934,” in Slavic Review Vol. 60 (Summer 2001), No. 2, p. 282. 
of agriculture, since younger peasants showed more willingness to join cooperatives than did their parents. ${ }^{112}$

The social structure that had come into existence in North Korea by the 1970s was more rigidly stratified and more immobile than Soviet society had been under Stalin. In mid-1964 the following groups were considered 'unreliable' by the North Korean regime: the family members of those who had fled to South Korea; the former members of the anti-Communist organizations created under US occupation; former prisoners-of-war, private entrepreneurs, and clergymen; persons of South Korean origin, intellectuals trained before 1945, and repatriates from Japan. The discriminative measures also affected the families of the persons in question. ${ }^{113}$ In 1964-1969 new categories were added to this list, and the percentage of 'unreliable elements' eventually reached some 25-30 per cent of the population. ${ }^{114}$ By contrast, the strata the CCP leadership considered 'hostile' constituted 8-10 per cent of the Chinese population in $1964 .{ }^{115}$ In the Russian SSR 3,5-3,9 per cent of all potential voters were lishentsy in the 1920 s and early 1930 s. ${ }^{116}$ As opposed to Kim Il-sung's DPRK, Stalin's policies were not directed toward the creation of an ossified caste system. On the one hand, social discrimination gradually abated. For instance, in December 1935 the Soviet regime abolished social criteria for entrance to higher education. ${ }^{117}$ On the other hand, one of the objectives of the Great Terror was the physical liquidation of 'former kulaks and counterrevolutionaries, 'church people,' 'sectarians,' and common criminals. In July 1937 Yezhov instructed local NKVD organs to execute 70,000 such persons altogether; 186,500 others were to be deported. ${ }^{118}$

In conclusion one may point out that the described differences between Soviet and North Korean policies refute the claim that Kim Il-sung proved incapable of the ,selective adoption of Stalinist traits ...he did not know what to leave

${ }^{112}$ Hungarian Embassy to the DPRK, Report, 9 February 1955, KA, 6. doboz, 12/a, 004063/1955; Hungarian Embassy to the PRC, Report, 2 November 1955, XIX-J-1-k [Administrative Documents] KHna 1945-1964 [henceforth CA], 18. doboz, 22/d, 004718/4/1955; Hungarian Embassy to the DRV, Report, 14 March 1962, XIX-J-1-j [Top Secret Documents] Vietnam 1945-1964 [henceforth VTS], 4. doboz, 5/c, 004098/1962. On the Soviet Komsomol, see, among others, Sheila Fitzpatrick, Stalin's Peasants, pp. 49-55, 59-60.

${ }^{113}$ Hungarian Embassy to the DPRK, Report, 1 June 1964, KTS, 13. doboz, 27/a, 004092/1964.

${ }^{114}$ See, among others, Helen-Louise Hunter, Kim Il-song's North Korea (Westport-London: Praeger Publishers, 1999), pp. 3-11.

${ }^{115}$ Hungarian Embassy to the PRC, Report, 4 July 1964, CTS, 8. doboz, 5/c, 004564/1964.

${ }^{116}$ Moshe Lewin, ,Society, State, and Ideology during the First Five-Year Plan,” in Cultural Revolution in Russia, 1928-1931. Edited by Sheila Fitzpatrick (Bloomington: Indiana University Press, 1984), p. 59.

${ }^{117}$ Sarah Davies, Popular Opinion in Stalin's Russia. Terror, Propaganda and Dissent, 1934-1941 (Cambridge: Cambridge University Press, 1997), pp. 69-70.

${ }^{118}$ Fitzpatrick, Stalin's Peasants, pp. 201-203. 
out, nor did he know how to leave it out." ${ }^{119}$ Certain similarities between the two regimes resulted from similar political and economic circumstances, rather than from blind imitation. In contrast with the post-1945 Yugoslav and Vietnamese party leaderships, in 1945-1956 the leadership of the KWP was as divided between various, though not necessary homogeneous, factions as the Bolshevik Party had been in the mid-1920s. It was this situation that enabled both Stalin and Kim Il-sung to play off their rivals against each other, destroying the latter one by one. Since North Korea inherited a quite developed industrial structure from Japanese colonialism, the Soviet model of modernization had much more relevance for it than for North Vietnam or other Third World countries. ${ }^{120}$ In the $1945-1953$ period Kim Il-sung had concerned himself primarily with the unification of Korea, and he subordinated the establishment of a full-blown Communist system to that goal. (The Soviets, on their part, seem to have agreed with this priority.) In the post-1953 period P'yongyang's increasing independence from Moscow further lessened the likelihood of indiscriminate imitation. Kim often resorted to Soviet methods to solve Korean problems, but he did not hesitate to modify or abandon them whenever it seemed necessary. In 1954-1955 KWP cadres (unlike their East European and Chinese counterparts) emphasized that there was no need to launch a campaign against 'kulaks.' In other cases, however, the policies of the North Korean regime were more radical than the measures taken by the East European dictatorships. During and after the Korean War, P'yongyang cracked down on the Catholic and Protestant churches, portraying Christianity as a religion alien to Korean culture and hostile to Korean nationalism. As a consequence, no organized Christian church remained in the DPRK by the mid-1950s. ${ }^{121}$ By contrast, the North Vietnamese and East European regimes (with the exception of Albania) were content with rigorous state control over the churches and the persecution of dissident clergymen. ${ }^{122}$

Nevertheless, the North Korean dictatorship did not diverge from the Soviet model as significantly as, say, the North Vietnamese regime did. The greatest

\footnotetext{
${ }^{119}$ Buzo, The Guerilla Dynasty, p. 49.

${ }^{120}$ Cumings, The Origins of the Korean War II, pp. 293., 336-337.

${ }^{121}$ Hungarian Embassy to the DPRK, Report, 14 May 1955, KTS, 12. doboz, 27/a, 006047/1955; Hungarian Embassy to the DPRK, Report, 4 December 1954, KTS, 6. doboz, 5/cb, 001142/1955; Hungarian Embassy to the PRC, Report, 14 April 1955, CA, 18. doboz, 22/d, 004719/1955.

${ }^{122}$ It is necessary to point out, however, that Christians had always constituted a minority in North Korea. Thus Kim Il-sung's policies were somewhat similar to the measures taken by the Bulgarian Communist dictatorship. The Chervenkov regime treated the Catholic and Protestant churches more harshly than the Orthodox church that represented the overwhelming majority of the population. For instance, in 1952 a Catholic bishop and three priests were sentenced to death, and soon after all Catholic priests, monks, and nuns were expelled from Bulgaria.
} 
purge the Vietnamese Workers' Party ever experienced took place in the course of the 1953-1956 land reform campaign, which was patterned after the Chinese model. By December 1955 the rent-reduction campaign had affected 7,77 million people, i.e. 63 per cent of the population. Of the 44,444 'landlords' identified, 3,939 were tried and 1,175 executed. The second stage of the campaign (the land reform proper) had affected 4 million people by December 1955 , of whom 18,738 were 'revealed' as 'concealed landlords' (these 'revelations' led to 3,312 trials and 162 executions). The scope of the repression can be gauged from that during the 'correction' of the land reform's 'errors' (1956-1957), the authorities released 23,748 political prisoners. ${ }^{123}$ By contrast, the North Korean land reform, though partly inspired by Chinese examples, proved essentially bloodless, as did the East European land reforms. ${ }^{124}$ The North Vietnamese land reform campaign was accompanied by a two-stage party purge. The VWP and the Youth League lost some 80,000 and 50,000 members respectively. By December 1955 32,200 persons had been expelled from the VWP, but only 10,501 new members entered the party. Since party membership stood at 324,000 in November 1955, these losses would have been high enough even if the regime had not dissolved nearly 80 per cent of the village and district party committees. ${ }^{125}$ While the magnitude of the purge was comparable to that of the East European Stalinist purges, its logic proved quite different. In North Vietnam the repressive measures did not affect the top leadership at all, though they moved up to the provincial level. While the security service played an active role in the hunt for 'saboteurs,' it was the land-reform cadres who were primarily responsible for the terror. By contrast, in the Soviet Union, Eastern Europe, and North Korea political repression remained, by and large, a monopoly of the security services. As opposed to the Soviet and North Korean dictatorships (but similarly to China), the North Vietnamese regime had a much weaker basis in the urban centers than in the countryside. In February 1955 the VWP had only 8,000 members in Hanoi, and on 21 April 1959 Pham Van Dong told a Hungarian diplomat that „the party is still very weak in the cities."

\footnotetext{
${ }^{123}$ Hungarian Embassy to the DRV, Report, 7 December 1955, VTS, 4. doboz, 5/c, 00419/1956; Hungarian Embassy to the DRV, Report, 20 September 1957, VTS, 4. doboz, 5/c, 002745/1/1957. See also Edwin E. Moise, Land Reform in China and North Vietnam. Consolidating the Revolution at the Village Level (Chapel Hill-London: The University of North Carolina Press, 1983).

${ }^{124}$ Bruce Cumings, The Origins of the Korean War I. Liberation and the Emergence of Separate Regimes 1945-1947 (Princeton: Princeton University Press, 1981), pp. 396-397, 414-417.

${ }^{125}$ Hungarian Embassy to the DRV, Report, 28 November 1955, VTS, 9. doboz, 27/d, 00426/1956; Hungarian Embassy to the DRV, Report, 29 May 1957, VTS, 9. doboz, 27/d, 003858/1957; Hungarian Embassy to the DRV, Report, 26 August 1956, VTS, 4. doboz, 5/c, 007218/1956; Hungarian Embassy to the DRV, Report, 10 July 1958, VTS, 4. doboz, 5/c, 00286/2/1958.

${ }^{126}$ Hungarian Embassy to the DRV, Report, 21 February 1955, XIX-J-1-k [Administrative Documents] Vietnam 1945-1964 [henceforth VA], 4. doboz, 15/b, 004128/1955; Hungarian Embassy to the PRC, Report, 23 May 1959, VTS, 2. doboz, 4/bc, 004110/1959.
} 
Thus the purge that shattered the rural organizations of the VWP undermined the regime's stability to such an extent that the leaders felt compelled to reexamine their policies, and rehabilitate tens of thousands of victims.

\section{Conclusion}

The policies of the various Communist regimes had a lot in common, but one should not regard all such similarities as the results of direct Soviet pressure. The following quotation from Liu Shaoqi reveals a lot about the psyche of Communist leaders. On 30 November 1963 the Chinese President discussed the negative consequences of the Great Leap Forward with some Hungarian diplomats. One of the latter described how disastrous the agricultural policy of the Rakosi regime had been in the 1950s, whereupon Liu replied: „We had heard of these experiences of yours. And we also had heard of the experiences of the Poles. That time, however, we did not give credence to it. We had not given credence to it until it also happened over here. Now it also occured over here, and now we have experiences of our own. Everybody considers his own experiences the most important." ${ }^{127}$ Practically every Communist regime underwent a phase of 'leftist deviation,' no matter whether it had direct contacts with Stalin's Soviet Union or not. Characteristically, in 1949 Tito reacted to Soviet criticism by speeding up collectivization. His security chief, Rankovic, planned to organize a show trial which should have ,proven" that the 'Cominformist' party leader Hebrang had been an Ustasha and Gestapo agent. Hebrang's wife and some of his acquaintances were indeed subjected to torture in order to extract false confessions from them. ,The split that emancipated the KPJ from the Soviet Union [initially] promoted home-grown Stalinism." ${ }^{128}$ As indicated earlier, the East European party purges were not rooted solely in the Stalin-Tito rift, and the repressive measures taken after the South-east European partisan takeovers revealed the substantial indigenous basis of Communist radicalism. While Soviet Stalinism did produce a decisive effect on the development of that radicalism, the latter's formative stage was not the 19441953 period but the 1920s and 1930s. In these decades the various Communist parties underwent a process of 'Bolshevization,' which resulted in the expulsion of many leaders who were inclined to think for themselves and reluctant to look up to the current Soviet Vozhd'. Following the Soviet-inspired purges of

\footnotetext{
${ }^{127}$ Hungarian Embassy to the PRC, Report, 29 December 1963, CTS, 2. doboz, 1/c, 001812/5/1964.

${ }^{128}$ Banac, With Stalin against Tito, pp. 120-121, 134-136.
} 
1937-1940, the CPY became the sort of party it would remain thereafter: a monolithic organization headed by Tito. ${ }^{129}$

The impact Stalin's USSR had on other countries manifested itself in various forms, both direct and indirect. As a neighboring country, it annexed territories at the expense of Finland, the Baltic states, Poland, Czechoslovakia, Romania, and Japan. As an occupying power, it enabled the Mongolian, East German, Polish, Hungarian, Romanian, and North Korean parties, some of which would not have been capable of seizing power, to establish Communist regimes. As the supreme patron of the 'little Stalins,' the Soviet dictator could, and did, shape the policies of most contemporary Communist dictatorships. Finally, the Soviet Union, as a political and economic system, served as an ideological model for parties and countries well beyond the reach of the MGB and the Red Army. Ideological influence was the widest of these concentric circles but also the weakest one. The Yugoslav case demonstrated that the enthusiastic adoption of Soviet methods was not necessary a guarantee for loyalty to the Soviet Union, since the subjective interests of the USSR did not always prove compatible with its role as the ideological center of the international Communist movement.

Due to the concentric circles of Soviet influence, the gradual transformation of Soviet Stalinism, and the tactical flexibility of the Soviet dictator, a paradoxical development took place in the Communist world. Certain Communist parties and regimes, such as Yugoslavia and Albania, resorted to Stalinist repressive measures without explicit Soviet encouragement, or even in defiance of Soviet directives. On the other hand, the Soviet Stalinist system was never adopted in its entirety. Of Stalin's loyal clients, only Choibalsan duplicated the Soviet Great Terror, but he did not carry out the collectivization of agriculture. Thus to ask whether there was one Communism or many Communisms is to pose a false antinomy. A certain intensity of repression (the 'minimal level') was characteristic of every Communist regime, but some dictatorships, such as the ones headed by Stalin, Hoxha, Choibalsan, Mao, Kim Il-sung, and Pol Pot, exceeded that level by far. While one cannot attribute every manifestation of Communist repression to Soviet influence, one cannot explain every aspect of Stalin's terror by pointing at Communist ideology. Although the framework of a Stalinist regime undoubtedly limited the number of alternatives a leader could take, certain alternatives did exist. Stalin's tactical flexibility highlights, rather than diminishes, his personal responsibility for the repressive measures he took. In the 1948-1953 period political paranoia was

${ }^{129}$ Ibid., 70-78. 
widespread enough in Eastern Europe, but it did not lead to a bloodbath comparable to the Soviet and Mongolian Great Purges. In addition, the dynamic of East European repression was not influenced by the 'Soviet model' alone: it was also shaped by the specific traditions of the local Communist parties, the latter's sociopolitical environment, and the events of World War II. 